\title{
Meningkatkan Hasil Belajar IPA Materi Sistem Pencernaan Manusia dengan Bahan Ajar Leaflet pada Siswa Kelas V SDN Sewar Tahun Pelajaran 2018/2019
}

\author{
Darsad \\ Guru Kelas Sekolah Dasar SDN Sewar Kec. Pujut Kab. Lombok Tengah
}

\begin{abstract}
Abstrak. Peneltian ini menggunakan penelitian tindakan kelas yang dilaksanakan dalam dua siklus. Adapun tujuan penelitian ini adalah untuk mengetahui peningkatan hasil belajar siswa kelas V SDN Sewar tahun pelajaran 2018/2019 setelah menggunakan Bahan Ajar Leaflet subjek penelitian ini adalah siswa kelas V SDN Sewar dengan jumlah siswa 21 siswa terdiri dari laki - laki 8 orang dan perempuan 13 orang. Teknik analisis data menggunakan data kuantitatif pengolahan hasil tes dengan menggunkan rumus prosentase. Berdasarkan hasil penelitian tindakan kelas yang telah dilaksanakan dalam dua siklus dapat disimpulkan bahwa terjadi peningkatan hasil belajar IPA materi Sistem Pencernaan Manusia dengan Bahan Ajar Leaflet pada siswa kelas V SDN Sewar Hal tersebut dapat dilihat dari hasil belajar siswa dalam proses pembelajaran yang semakin meningkat dalam setiap siklusnya, yaitu dari 21 jumlah siswa nilai rata- rata siklus ! sebesar 63,71 meningkat siklus II sebesar 87,33 terjadi peningkatan sebesar 23,62 poin Demikian juga dengan prosentase ketuntasan siswa yang semula pada siklus I sebesar $48 \%$ atau sebanyak 10 siswa mendapat nilai $\geq 70$, sedangkan pada siklus II meningkat menjadi $90 \%$ atau sebanyak 19 siswa mendapat nilai $\geq 70$ dengan tingkat ketuntasan klasikal $\geq 80$ sehingga penelitian di hentikan pada siklus II, Dengan demikian dapat disimpulkan dengan menggnakan media Leaflet dapat meningkatkan hasil belajar IPA materi sistem pencernaan manusiapada siswa Kelas V SDN Sewar Tahun Pelajaran 2018/2019.
\end{abstract}

Kata kunci: Hasil Belajar, Bahan Ajar Leaflet

\section{PENDAHULUAN}

\section{Latar Belakang Masalah}

Bahan ajar adalah segala bentuk bahan atau materi yang disusun secara sistematis yang digunakan untuk membantu guru atau instruktur dalam melaksanakan kegiatan belajar mengajar sehingga tercipta lingkungan atau suasana yang memungkinkan siswa untuk belajar. Bahan ajar disebut juga teaching-materia. Hamdani (2011;120). Bahan ajar salah satu sarana untuk mempermudah penyampaian materi dari guru kepada siswa, dengan adanya bahan ajar atau alat-alat penunjang, proses pembelajaran akan memberikan pandangan bahwa guru atau instruktur bukanlah satusatunya sumber belajar. Bahan ajar dapat mewakili apa yang kurang mampu guru ucapkan melalui kata-kata atau kalimat tertentu. Penggunaan bahan ajar diharapkan dapat meningkatkan proses pembelajaran siswa yang pada akhirnya diharapkan dapat meningkatkan hasil belajar yang dicapai.

Bentuk bahan ajar dapat dikelompokkan menjadi empat, yaitu: (a) Bahan ajar cetak (printed) antara lain handout, buku, modul, lembar kerja siswa, brosur, leaflet, wallchart, foto/gambar, dan non cetak (non printed), seperti model atau maket. (b) Bahan ajar dengar (audio) seperti kaset, radio, piringan hitam, dan compact disk audio. (c) Bahan ajar pandang dengar (audio visual) seperti video compact disk, film. (d) Bahan ajar interaktif (interactive teaching material) seperti compact disk interaktif . Abdul Majid (2006;170).

Leaflet merupakan bahan ajar berbentuk selembaran kertas yang diberi gambar dan tulisan (biasanya lebih banyak berisi tulisan) pada kedua sisi kertas serta dilipat sehingga berukuran kecil dan praktis dibawa. Leaflet biasanya berukuran A4 yang dilipat tiga' Roymond H. Simamora (2009; 70-71). Leaflet adalah salah satu bentuk bahan ajar cetak yang berisikan rangkuman materi pelajaran. Materi pelajaran tersebut diambil dari beberapa sumber belajar baik buku maupun internet yang dijadikan satu dalam bentuk leaflet. Agar terlihat menarik biasanya leaflet di desain secara cermat dilengkapi dengan ilustrasi atau gambar- 
gambar dengan menggunakan bahasa yang sederhana, singkat serta mudah dipahami.

Hal ini berbeda dengan hasil ulangan harian materi Sistem Pencernaan manusia pada siswa kelas V SDN Sewar jumlah siswa 21 yang tuntas belajar hanya 9 siswa dengan persentase ketuntasan sebesar $43 \%$ dan siswa yang belum tuntas sebanyak 12 orang atau persentase sebesar $57 \%$ dan KKM yang di patok SDN Sewar Untuk Pelajaran IPA di kelas V adalah 70 dengan ketuntasan klasikal sebesar $\geq 80$, pada tahun pelajaran 2018 / 2019.

Ternyata kendala penyebab dari rendahnya hasil belajar IPA siswa kelas V adalah bahan ajar yang digunakan tidak menarik, metode pembelajaran yang tidak tepat. Hal ini menjadi penyebab mereka lekas bosan dan tidak tertarik pada pelajaran IPA karena guru yang menyampaikan materi pelajaran tidak mampu mengembangkan dan membentuk kemandirian peserta didik, melainkan mengarah kepada pembentukan sikap yang pasif, kurang percaya diri, dan tidak terlatih berfikir kritis guna mengembangkan penalarannya (Gufron Amirullah. 2007;113).

Beberapa penyebab diatas menyebahkan hasil belajar siswa rendah. Hasil belajar adalah suatu puncak proses pembelajaran. Suatu proses pembelajaran dinyatakan berhasil apabila hasilnya memenuhi tujuan dari proses pembelajaran tersebut. Hasil belajar merupakan perubahan tingkah laku setelah siswa melakukan serangkaian kegiatan belajar yang menyangkut kognitif, afektif, dan psikomotorik( Nana Sudjana 2009;3). Perubahan yang dimaksud adalah perubahan yang sesuai dengan tujuan pembelajaran. Keberhasilan pembelajaran merupakan keberhasilan siswa dalam membentuk kompotensi dan mencapai tujuan, serta keberhasilan guru dalam membimbing siswa dalam pembelajaran. Hasil belajar dalam proses pembelajaran sangat lah penting, orang yang mendapatkan hasil belajar sesuai harapan berarti memperoleh keberhasilan atau kesuksesan, semua orang pasti menginginkan harapan, cita-cita dan keinginannya tercapai. Memperoleh prestasi sesungguhnya merupakan dambaan setiap siswa. Salah satu bahan ajar yang dapat digunakan untuk meningkatkan hasil belajar siswa adalah bahan ajar leaflet

Atas dasar hal tersebut peneliti tertarik untuk melakukan penelitian dengan judul "Meningkatkan Hasil Belajar IPA Materi Sistem Pencernaan Manusia dengan Bahan Ajar Leaflet pada Siswa Kelas V SDN Sewar Tahun Pelajaran 2018/2019.

\section{Rumusan Masalah}

Berdasarkan latar belakang masalah diatas maka dirumuskan masalah, “ Bagaimanakah Meningkatkan Hasil Belajar IPA Materi Sistem Pencernaan Manusia dengan Bahan Ajar Leaflet pada Siswa Kelas V SDN Sewar Tahun Pelajaran 2018/2019?.

\section{Tujuan Penelitian}

Tujuan dari penelitian ini adalah untuk Meningkatkan Hasil Belajar IPA Materi Sistem Pencernaan Manusia dengan Bahan Ajar Leaflet pada Siswa Kelas V SDN Sewar Tahun Pelajaran 2018/2019.

\section{Manfaat Penelitian}

Melalui hasil ini, diharapkan dapat memberikan motivasi bagi guru dan sebagai masukan dalam memilih Media, bahan ajar yang tepat dalam pembelajaran IPA di SD dalam meningkatkan hasil belajar siswa .

\section{LANDASAN TEORI DAN \\ KAJIAN PUSTAKA \\ Hakikat dan Karakteristik IPA di SD}

Hakikat IPA memiliki empat unsur yang utama yaitu pertama, sikap ingin tahu tentang benda, fenomena alam, mahluk hidup serta hubungan sebab akibat yang menimbulkan masalah baru yang dapat dipecahkan melalui prosedur yang benar. Kedua,proses prosedur pemecahan masalah: Metode ilmiah meliputi penyusunan hipotesis, perencanaan, eksperimen, evaluasi, pengukuran dan penarikan kesimpulan. Ketiga, Produk: berupa fakta, prinsip, teori dan hukum. Keempat, Aplikasi: penerapan metode dan konsep IPA dalam kehidupan sehari-hari. Keempat unsur tersebut merupakan ciri IPA yang utuh serta tidak dapat dipisahkan satu sama lain" ( Triyanti; $2010 ; 100)$

\section{Hakikat Belajar}

Sejak manusia diciptakan, sebenarnya 
ia telah melaksanakan aktivitas belajar. Oleh karena itu, dikatakan bahwa aktivitas belajar itu telah ada sejak adanya manusia. Belajar merupakan salah satu kebutuhan bagi manusia, karna manusia adalah makhluk belajar yang di dalam dirinya terdapat potensi untuk diajar.

Belajar merupakan perubahan perilaku berkat pengalaman dan latihan. Artinya tujuan dari belajar itu sendiri adalah adanya perubahan tingkah laku, baik yang menyangkut pengetahuan, keterampilan maupun sikap, bahkan meliputi segenap aspek organisme atau pribadi. Syaiful Bahri Djamarah ( 2006;10-11).

Beberapa ahli yang berpendapat mengenai arti belajar dalam unsur perubahan seseorang diantaranya Bower dan Hilgard yang dikutip oleh Udin menyatakan bahwa : “ Belajar mengacu pada perubahan perilaku atau potensi individu sebagai hasil dari pengalaman dan perubahan tersebut tidak disebabkan oleh insting, kematangan atau kelelahan dan kebiasaan (Udin S Winataputra 2007; 1.8)".

Belajar menurut psikologi behavioristik yang dikutip oleh Ali Imron menyatakan bahwa : " Belajar adalah suatu control instrument yang berasal dari lingkungan (Ali Imron, 2006;5). Menurut Thorndike, belajar dapat dilakukan dengan mencoba-coba (Trial and Error). Mencobacoba ini dilakukan manakala seseorang tidak tahu bagaimana harus memberikan respon atas sesuatu (Ali Imron. 2006; 8).

Dari definisi tersebut jelas bahwa belajar tidak hanya berkenaan dengan jumlah pengetahuan saja tetapi meliputi seluruh kemampuan individu, yang berpusat pada :

a Belajar harus memungkinkan terjadinya perubahan perilaku pada diri individu. Perubahan tersebut tidak hanya pada aspek pengetahuan atau kognitif saja tetapi juga meliputi aspek sikap dan nilai (afektif) serta keterampilan (psikomotor).

b. Perubahan itu harus merupakan buah dari pengalaman. Perubahan perilaku yang terjadi pada diri individu karena adanya interaksi antara dirinya dengan lingkungan.

c. Perubahan yang relatif menetap.
Artinya belajar sebagai suatu perubahan tingkah laku dalam diri seseorang yang relatif menetap sebagai hasil dari sebuah pengalaman.

Menurut psikologi kognitif menyatakan bahwa belajar adalah sebagai suatu usaha untuk mengerti tentang sesuatu. Usaha untuk mengerti tentang sesuatu tersebut, dilakukan secara aktif oleh pembelajar(Ali Imron. 1996;;10).

Belajar menurut pandangan psikologi humanistik manyatakan bahwa : "Belajar merupakan cara memberikan kebebasan yang sebesar- besarnya kepada individu (Ali Imron. 2006; 11). Kebebasan dalam hal ini adalah kebebasan individu untuk berfikir dan mengeluarkan ide-ide dari apa yang telah dipelajarinya dan dipahami oleh individu melalui proses balajar.

Perubahan belajar dapat terjadi apabila seseorang telah mengalami proses belajar- mengajar. Bell-Gredler yang dikutip oleh Udin menyatakan bahwa : "Belajar adalah proses yang dilakukan oleh manusia untuk mendapatkan aneka ragam kemampuan, keterampilan, dan sikap yang diperoleh dari secara bertahap dan berkelanjutan mulai dari masa bayi sampai masa tua melalui rangkaian proses belajar sepanjang hayat". Rangkaian belajar tersebut dilakukan dalam bentuk keterlibatannya dalam pendidikan informal, keturutsertaannya dalam pendidikan formal dan pendidikan nonformal (Udin,dkk.Op cit $1.5)$.

Menurut pandangan psikologi gestalt, menyatakan bahwa : " Belajar terdiri atas hubungan respon yang sederhana tanpa adanya pengulangan ide atau proses berfikir (Ali Imran. Op cit. hlm.14).

Di mana dalam proses pendidikan ini, manusia mengalami proses perubahan belajar yang ditandai dengan adanya keingintahuan seseorang terhadap sesuatu, sehingga melalui proses belajar mengajar manusia mendapatkan pengalaman dan diikuti dengan perubahan dari apa yang telah dipelajarinya. Semakin aktif seseorang berinteraksi dalam proses belajar mengajar semakin baik pula perubahan yang terjadi dalam diri seseorang yang sedang belajar.

1). Pengertian IPA

Secara umum IPA didefinisikan 
sebagai suatu sistem dalam mempelajari alam melalui pengumpulan data dengan cara observasi dan percobaan yang terkendali. Setelah data dikumpulkan baru dapat dikemukakan teori yang lebih jauh untuk menjelaskan apa yang telah diteliti.

IPA membahas tentang gejala-gejala alam yang disusun secara sistematis yang didasarkan pada hasil percobaan dan pengamatan yang dilakukan oleh manusia. Hal ini sesuai dengan yang dikemukakan oleh Powler yang menyatakan bahwa: IPA merupakan ilmu yang berhubungan dengan gejala-gejala alam dan kebendaan yang sistematis yang tersusun secara teratur, berlaku umum yang berupa kumpulan dari hasil observasi dan eksperimen (Usman Samatowa. 2006; 2).

Akan tetapi IPA juga sering digambarkan hanya sekedar kumpulan hukum dan katalog dari fakta-fakta yang tidak berhubungan. Gambaran yang sempit tersebut akhirnya akan mempengaruhi cara menyikapi IPA sebagai hal yang rumit dan membosankan.

Selain itu, Nash 2003 yang dikutip oleh Usman Samatowa dalam bukunya The Nature of Sciences menyatakan bahwa IPA itu adalah suatu cara atau metode untuk mengamati alam. Nash juga menjelaskan bahwa cara IPA mengamati dunia bersifat analisis, lengkap, cermat, serta menghubungkan antara satu fenomena dengan fenomena lain, sehingga keseluruhannya membentuk suatu perspektif yang baru tentang objek yang diamatinya (Usman Samatowa logcit;2)

Secara singkat dapat dikatakan IPA merupakan suatu usaha manusia dalam memahami alam semesta melalui pengamatan yang tepat (correct) pada sasaran, serta menggunakan prosedur yang benar dan dijelaskan dengan penalaran yang valid sehingga dihasilkan kesimpulan yang betul (Budi Akbar. 2010;37). Jadi, IPA mengandung tiga hal, yaitu proses (usaha manusia memahami alam semesta), prosedur (pengamatan yang tepat dan prosedurnya tepat), dan produk (kesimpulan yang betul).

IPA membahas kenyataan, faktafakta dan teori-teori melalui kerja yang dilakukan untuk dapat memecahkan ilmu- ilmu yang terdapat di alam ini yang pada akhir didapatkan produk sains (hasil IPA) yang berupa fakta, konsep, prinsip, Berdasarkan analisis laporan proyek sintesis, sains dapat disimpulkan bahwa pengajaran IPA orientasinya harus berubah, tidak lagi menekan pada struktur keilmuannya dan menyiapkan siswa untuk menjadi saintis semata, tetapi harus lebih manusiawi dan membekali siswa untuk menghadapi maslahmasalah yang berhubungan dengan sains dan teknologi dalam kehidupan sehari-hari(Nono Sutarno. 2009;9.12). Dari definisi tersebut maka hakikat IPA dalam penelitian ini adalah sebagai proses yang merujuk pada suatu aktivitas ilmiah atau kerja cara memperoleh hasil IPA. Dalam mengajar IPA tidak berarti hanya menstransfer materi IPA yang terdapat dibuku lebih jauh siswa diajak masuk ke dalam alam yang konkret melalui cara mengajak siswa melakukan pengamatan sendiri untuk menemukan jawaban dari apa yang diamati.

\section{Hakikat Hasil Belajar}

Tujuan proses belajar-mengajar pada hakikatnya adalah sejumlah hasil yang menunjukkan bahwa siswa telah melakukan perbuatan belajar, yang umumnya meliputi pengetahuan, keterampilan dan sikap-sikap yang baru, yang diharapkan dapat dicapai oleh siswa. Hal ini sesuai dengan pendapat Abdurrahman yang dikutip oleh Asep bahwa : "Hasil belajar adalah kemampuan yang diperoleh anak setelah melalui kegiatan belajar. Belajar itu sendiri merupakan suatu proses dari seseorang yang berusaha untuk memperoleh suatu bentuk perubahan perilaku yang relative menetap (Asep Jihad, dkk. 2008;14)

Setelah melalui proses belajar maka siswa dapat mencapai tujuan belajar yang disebut juga sebagai hasil belajar yaitu kemampuan yang dimiliki siswa setelah menjalani proses belajar. Nana Menyatakan bahwa :Hasil belajar adalah kemampuankemampuan yang dimiliki siswa setelah ia menerima pengalaman belajarnya (Nana Sudjana. 2009;22).

Hasil belajar diperoleh dari evaluasi pembelajaran. Evaluasi itu sendiri menurut Wand dan Brown menyatakan bahwa :" Evaluasi adalah suatu tindakan atau suatu 
proses untuk menentukan nilai dari sesuatu (Made Wena. 2009:50)

Menurut Dimyanti berpendapat bahwa "Evaluasi hasil belajar merupakan proses untuk menentukan nilai belajar siswa melalui kegiatan penilaian atau pengukuran hasil belajar (Dimyanti,dkk. 2006:200)

Dari uraian tersebut telah dipaparkan, maka hakikat hasil belajar dalam penelitian ini adalah hasil akhir pengambilan keputusan mengenai tinggi rendahnya nilai yang diperoleh siswa selama mengikuti proses pembelajaran. Hasil belajar dikatakan tinggi apabila kemampuan siswa bertambah dari hasil sebelumnya.

\section{Bahan Ajar}

Bahan ajar adalah segala bentuk bahan atau materi yang disusun secara sistematis yang digunakan untuk membantu guru atau instruktur dalam melaksanakan kegiatan belajar mengajar sehingga tercipta lingkungan atau suasana yang memungkinkan siswa untuk belajar. Bahan ajar disebut juga teaching-material Hamdani (2011; 120).

Menurut Sanjaya, bahan atau materi pelajaran adalah segala sesuatu yang menjadi isi kurikulum yang harus dikuasai oleh siswa sesuai dengan kompetensi dasar dalam rangka pencapaian standar kompetensi setiap mata pelajaran dalam satuan pendidikan tertentu. Sedangkan Majid mengungkapkan bahwa bahan ajar adalah segala bentuk bahan yang digunakan untuk membantu guru/instruktur dalam melaksanakan kegiatan belajar mengajar di kelas. Bahan yang dimaksud bisa berupa bahan tertulis maupun bahan tidak tertulis" Roymond H. Simamora( 2009;70-71).

\section{Leaflet}

Leaflet adalah bahan ajar cetak tertulis berupa lembaran yang dilipat tapi tidak dimatikan. Agar terlihat menarik biasanya leaflet didesain secara cermat dilengkapi dengan ilustrasi dan menggunakan bahasa sederhana, singkat serta mudah dipahami. Leaflet sebagai bahan ajar juga harus memuat materi yang dapat mengiringi peserta didik untuk menguasai satu atau lebih kompetensi dasar' Abdul majid (2006;177). Leaflet merupakan media berbentuk selembar kertas yang diberi gambar dan tulisan (biasanya lebih banyak tulisan) pada kedua sisi kertas serta dilipat sehingga berukuran kecil dan praktis dibawa . Biasanya ukuran A4 dilipat tiga' Falasipah (2015; 15)'

Leaflet adalah bentuk penyampaian informasi atau pesan-pesan melalui lembaran kertas yang dilipat, isi informasi dapat berupa kalimat, gambar, atau kombinasi Sedangkan Kholid mendefinisikan leaflet adalah suatu bentuk media publikasi yang berupa kertas selebaran dengan ukuran tertentu, disajikan dalam bentuk lembaran kertas berlipat (pada umumnya 2-3 lipatan) dan tanpa jilid.

Berbagai definisi leaflet diatas, dapat disimpulkan bahwa leaflet adalah bahan ajar cetak berupa satu lembar kertas yang dilipat menjadi beberapa bagian yang berisi mengenai pesan-pesan atau informasi yang dalam hal ini berupa materi pelajaran dan dilengkapi dengan ilustrasi atau gambar.

\section{Keunggulan Dan Kelemahan Leaflet}

Menurut Nursamsiah (2013'27)

Leaflet memiliki keunggulan dan kelemahan. Keunggulan leaflet antara lain leaflet efektif untuk pesan singkat, sederhana dan murah, siswa dapat belajamandiri, pengguna dapat melihat isinya pada saat santai, dapat memberikan detil (misalnya statistik) yang tidak mungkin bila disampaikan lisan, siswa dan guru dapat mempelajari informasi yang rumit bersama- sama.

Sedangkan kelemahan leaflet adalah leaflet mudah hilang dan rusak, dapat menjadi kertas percuma kecuali guru secara aktif melibatkan siswa dalam membaca dan menggunakan materi dan pesan yang disampaikan terbatas.

\section{METODE PENELITIAN}

\section{Tempat, waktu, dan subyek Penelitian}

Penelitian tindakan kelas ini dilaksanakan di SDN Sewar Kecamatan Pujut kabupaten lombok Tengah, dilaksanakan dari bulan Januari sampai Maret 2019 pada semester genap tahun pelajaran 2018/2019. Penelitian ini dilakukan pada siswa kelas $\mathrm{V}$ yang berjumlah 21 Orang dengan rincian siswa laki - laki berjumlah 8 orang dan siswa perempuan berjumlah 13 orang. 
Dengan merujuk pada permasalahan yang telah dijelaskan pada bab ini sebelumnya, maka metode penelitian yang akan digunakan adalah penelitian tindakan kelas, yaitu kegiatan penelitian untuk mendapatkan kebenaran dan manfaat praktis dengan cara melakukan tindakan secara kolaboratif dan inspiratif (Sutarto, 2013;6).

Dengan media Leaflet ini siswa berkreasi memadukan seni dalam membuat rangkuman dengan didesain sesuai kreatifitas sehingga siswa merasa tertarik untuk membaca dan mudah untuk memahami pengetahuan yang disampaikan oleh guru, disamping itu siswa ditantang untuk menghubungkan pengetahuan yang pernah dialamai, dirasakan sehingga siswa menemukan, dan mengeksplorasi pengetahuan tersebut dengan apa yang telah mereka ketahui sendiri. Adapun dalam penelitian tindakan kelas ini ada empat tahapan yang dilalui, yaitu: Tahap Perencanaan, Tahapan Pelaksanaan Tindakan, Tahapan Pengamatan, Tahapan Refleksi

Prosedur pelaksanaan penelitian tindakan kelas ini disajikan dalam bentuk peroses pengkajian berdaur (siklus) yang digambarkan dalam bentuk spiral yang sering disebut spiral PTK. Untuk memahami bentuk spiral PTK digambarkan sebagai berikut:

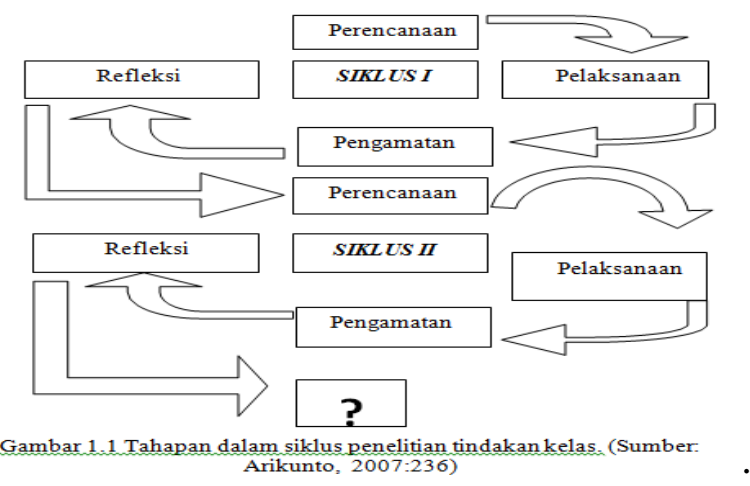

\section{Teknik Pengumpulan Data}

Teknik pengumpulan data yang digunakan dalam penelitian ini yaitu tes. Adapun langkah-langkah pengolahan data yang terkumpul dari setiap siklus adalah: Menentukan rata-rata dari seluruh siswa yang mengikuti tes.Tingkat keberhasilan siswa yang berdasarkan skor tes yang diperoleh ditetapkan dalam nilai dengan menggunakan rumus:

$$
\mathrm{NA}=\frac{\sum \text { Perolehan }}{\text { Skor Maksimal }} \times 100
$$

Menentukan nilai ketuntas belajar ; Tingkat ketuntasan secara klasikal dihitung dengan rumus $(\mathrm{P})=\frac{\sum \mathrm{Ns}}{\sum \mathrm{s}} \times 100$

Keterangan;

$\mathrm{P}=$ Ketutasan klasikal

$\sum \mathrm{s}=$ nilai seluruh siswa

$\sum \mathrm{s}=$ jumlah sisw

\section{HASIL PENELITIAN DAN PEMBAHASAN}

Data Hasil Penelitian

Dari kegiatan pembelajaran dan perbaikan pembelajaran yang telah dilakukan peneliti melalui media leaflet, peneliti memperoleh data dari mulai proses kegiatan sampai refleksi dari kedua siklus. Untuk lebih terperincinya laporan hasil penelitian dalam setiap siklus diuraikan sebagai berikut: Siklus I

Siklus I dilaksanakan pada hari Senin, 7 Januari 2019 dengan alokasi waktu 2 x 40 menit pada jam pertama dan setiap awal kegiatan belajar mengajar, diawali dengan kegiatan berdo'a, kemudian mengabsen siswa, selanjutnya menyampaikan tujuan pembelajaran yang akan dipelajari. Guru menjelaskan tujuan pembelajaran, menjelaskan logistik yang dibutuhkan dan memotivasi siswa agar terlihat langsung dan aktif pada aktivitas pembelajaran dengan leaflet pada materi Sistem Pencernaan Manusia.

Setelah proses pembelajaran dengan menggunakan Bahan ajar leaflet kemudian dillakukan evaluasi terhadap hasil belajar maka dapat diperoleh hasil ulangan Nilai rata - rata yang diperoleh siswa adalah sebesar 63,71 kemudian siswa yang tuntas sebanyak 10 orang atau persentase sebesar $48 \%$ dan siswa yang belum tuntas sebanyak 11 orang atau persentase sebesar $52 \%$ ini terjadi karena Dalam kegiatan pembelajaran pada siklus I ini, hasil belajar siswa masih rendah dikarenakan siswa masih belum paham dengan media yang digunakan sehingga perhatian siswa masih kurang, belum muncul ide baru Proses pembelajaran dengan Leaflet dengan demikian peneltian 
dilanjutan ke siklus II.

Siklus II

Siklus II dilaksanakan pada hari Senin tanggal 21 Januari 2019 dengan alokasi waktu 2 x 40 menit, kegiatan dilakukan pada jam I dan II kegiatan tidak jauh berbeda dengan siklus I hanya dilengkapi kekurangan - kekurangannya, peneliti kemudian menjelaskan kepada siswa tentang materi yang akan dipelajari dan tujuan pembelajaran pada siklus II.

Pada pertemuan siklus II dengan menggunkan media leaflet siswa merasa tidak asing lagi, siswa merasa senang dalam proses pembelajaran dan pada kegiatan akhir diadakan evaluasi dan hasil belajar siswa dimana Nilai rata - rata yang diperoleh siswa adalah sebesar 87,33 kemudian siswa yang tuntas sebanyak 19 orang atau persentase sebesar $90 \%$ dan siswa yang belum tuntas sebanyak 2 orang atau persentase sebesar $10 \%$ ini terjadi karena dalam kegiatan pada siklus II, hasil belajar siswa terjadi peningkatan dibandingkan dengan siklus I. Siswa sudah mulai dapat berkreasi dan rasa percaya diri tinggi tanpa takut salah mengerjakan tugas, dalam kegiatan ini guru berusaha menjelaskan materi dan mengaitkan materi yang sedang dipelajari dengan materi Sistem Pencernaan Manusia dan mampu menghubungkan pelajaran dengan kehidupan sehari-hari. Dan ketuntasan klasikal yang dipersyaratkan sebesar $80 \%$ juga sudah tercapai maka dengan demikian penelitian ini dihentikan sampai pada siklus II.

Dari hasil pengamatan dan evaluasi pada siklus II dapat direfleksikan hasil pengamatan terhadap siswa, guru, maupun evaluasi menunjukkan hasil yang sudah baik. Leaflet ini akan membuat siswa semakin suka dan senang belajar IPA,

\section{Pembahasan}

Hasil penelitian tindakan kelas yang dilaksanakan di kelas V SDN Sewar hasil belajar siswa pada Materi Sistem Pencernaan Manusia dengan Bahan Ajar leatlet yang pelaksanaannya dilakukan dua siklus menunjukkan adanya peningkatan hasil belajar.

Hasil belajar siswa pada siklus I Nilai rata - rata yang diperoleh siswa adalah sebesar 63,71 kemudian siswa yang tuntas sebanyak 10 orang atau persentase sebesar $48 \%$ dan siswa yang belum tuntas sebanyak 11 orang atau persentase sebesar $52 \%$ ini terjadi karena Dalam kegiatan pembelajaran pada siklus I ini, hasil belajar siswa masih rendah dikarenakan siswa masih belum paham dengan media yang digunakan sehingga perhatian siswa masih kurang, belum muncul ide baru Proses pembelajaran dengan Leaflet dengan demikian peneltian dilanjutan ke siklus II.

Sedangkan Hasil belajar siswa pada siklus II Nilai rata - rata yang diperoleh siswa adalah sebesar 87,33 kemudian siswa yang tuntas sebanyak 19 orang atau persentase sebesar $90 \%$ dan siswa yang belum tuntas sebanyak 2 orang atau persentase sebesar $10 \%$ ini terjadi karena dalam kegiatan pada siklus II, hasil belajar siswa terjadi peningkatan dibandingkan dengan siklus I. Siswa sudah mulai dapat berkreasi dan rasa percaya diri tinggi tanpa takut salah mengerjakan tugas, dalam kegiatan ini guru berusaha menjelaskan materi dan mengaitkan materi yang sedang dipelajari dengan materi Sistem Pencernaan Manusia dan mampu menghubungkan pelajaran dengan kehidupan sehari-hari. Dan ketuntasan klasikal yang dipersyaratkan sebesar $80 \%$ juga sudah tercapai maka dengan demikian penelitian ini dihentikan sampai pada siklus II.

Jika dibandingkan hasil belajar siswa dari siklus I menuju siklus II terjadi peningkatan hasil yang cukup signifikan, pada siklus I nilai rata - rata yang diperoleh sebesar 63,71 meningkat pada siklus II menjadi 87,33 terjadi peningkatan sebesar 23,62 poin kemudian jumlah siswa yang tuntas belajar pada siklus II sebanyak 10 orang dengan persentase sebesar $48 \%$ kemudian meningkat pada siklus II menjadi 19 orang siswa yang tuntas dengan persentase sebesar $90 \%$ terjadi peningkatan sebesar 42 poin.

Maka dengan demikian dapat disimpulkan bahwa penggunaan media leaflet dapat meningkatkan hasil belajar siswa kelas V SDN Sewar kecamatan Pujut tahun pelajaran 2018 / 2019.

\section{PENUTUP}

Berdasarkan hasil penelitian tindakan kelas yang telah dilaksanakan dalam dua siklus dapat disimpulkan bahwa terjadi peningkatan hasil belajar IPA siswa kelas V SDN Sewar pada materi Sistem Pencernaan Manusia dengan Media Leaflet . Hal tersebut dapat dilihat dari hasil belajar siswa dalam 
proses pembelajaran yang semakin meningkat Universitas Terbuka.

dalam setiap siklusnya

Jika dibandingkan hasil belajar siswa dari siklus I menuju siklus II terjadi peningkatan hasil yang cukup signifikan, pada siklus I nilai rata - rata yang diperoleh sebesar 63,71 meningkat pada siklus II menjadi 87,33 terjadi peningkatan sebesar 23,62 poin kemudian jumlah siswa yang tuntas belajar pada siklus II sebanyak 10 orang dengan persentase sebesar $48 \%$ kemudian meningkat pada siklus II menjadi 19 orang siswa yang tuntas dengan persentase sebesar $90 \%$ terjadi peningkatan sebesar 42 poin.

\section{DAFTAR PUSTAKA}

Abdul Majid. Perencanaan Pembelajaran Mengembangkan Standar

Kompetensi Guru. Bandung: PT. Remaja Rosdakarya. 2006.

Anggoro,Toha(2007). Metodologi Penelitian. Jakarta : Universitas Terbuka.

Arikunto, Suharsimi. (2007). Evaluasi Pendidikan. Jakarta : Bumi Aksara.

Bahri, Syaiful, dkk (2006). Strategi Belajar Mengajar. Jakarta : Pt. Rineka Cipta.

Cinde Futriyah. Penggunaan Bahan Ajar Leaflet Terhadap Aktivitas Belajar Dan Penguasaan Materi Oleh Siswa. Lampung: Universitas Lampung. Jurnal. 2013

Dimyanti,dkk(2006). Belajar dan Pembelajaran. Jakarta : Rineka Cipta.

Endah Tri Septiani dkk. Penggunaan Bahan Ajar Leaflet Terhadap Hasil Belajar Siswa. Lampung : Universitas Lampung. Jurnal Vol 2, No 4. 2013.

Kesuma, Dharma,dkk (2010). Contextual Teaching and Learning. Garut : Rahayasa Research and Training.

Roymond H. SimamoraBuku. Ajar Pendidikan dalam Keperawatan. Jakarta: Buku Kedokteran EGC. 2009.

Sudjana, Nana( 2009). Penilaian Hasil Proses Belajar Mengajar. Bandung : Remaja Rosdakarya.

S, Udin,dkk (2007). Teori Belajar dan Pembelajaran. Jakarta : Universitas Terbuka.

Sutarno, Nono( 2009). Materi dan Pembelajaran IPA SD. Jakarta : 